\title{
Development of Polylactic Acid and Bovine Serum Albumin-layered-coated Chitosan Microneedles Using Novel Bees Wax Mould
}

\author{
Yeni Balmumu Kalıbı Kullanılarak Polilaktik Asit ve Sığır Serum Albümin \\ Tabakalı Kaplanmış Kitosan Mikroiğnelerinin Geliştirilmesi
}

\author{
(D) Ravindra V BADHE*, (D) Deepak ADKINE, (D) Anagha GODSE \\ Department of Pharmaceutical Chemistry, Dr. D. Y. Patil Institute of Pharmaceutical Sciences and Research, Pimpri, Pune, Maharashtra, India
}

\begin{abstract}
Objectives: This work illustrates a novel method of fabrication of polymeric microneedle (MN) construct using bees wax as mould and development of coated polymeric MNs for drug delivery.

Materials and Methods: A novel method of MN fabrication using bees wax as mould was established. The porous chitosan MN arrays were fabricated and coated with polylactic acid (PLA). The optimized MN arrays were coated with bovine serum albumin (BSA). The MNs were subjected to physiochemical and tensile strength characterization, followed by drug release study. The skin penetration and irritation study were performed in vivo in Wistar Albino rats.

Results: The constructed MN arrays contain MNs with $0.9 \mathrm{~mm}$ length, $600 \mu \mathrm{m}$ width at the base, 30-60 $\mu \mathrm{m}$ diameter at the tip, and $1.5 \mathrm{~mm}$ distance between 2 needles. These MNs patch was having good mechanical strength ( $0.72 \mathrm{~N} /$ needle) and tensile strength $15.23 \mathrm{Mpa}$. The MN array patch had $6.26 \%$ swelling index and $98.5 \%$ drug release was observed on the $50^{\text {th }} \mathrm{hr}$. Good penetration and no skin irritation was observed for optimized MN batch.

Conclusion: Polymeric MN arrays were successfully developed using bees wax mould and were successfully coated with PLA to deliver the BSA through skin epidermis layer.
\end{abstract}

Key words: Microneedles, transdermal drug delivery, coated microneedles, microneedle mould, bees wax, polylactic acid

ÖZ

Amaç: Bu çalışma, arı balmumunun kalıp olarak kullanıldığı polimerik mikroiğnelerin (MN) üretimine ilişkin yeni bir yöntemi ve ilaç taşınımı için kaplanmış polimerik MN'lerin geliştirilmesini amaçlamaktadır.

Gereç ve Yöntemler: Kalıp olarak arı balmumu kullanan yeni bir MN üretim yöntemi olușturulmuștur. Gözenekli kitosan MN dizileri üretilmiș ve polilaktik asit (PLA) ile kaplanmıștır. Optimize edilmiş MN dizileri, sığır serum albümini (BSA) ile kaplandı. MN'ler, fizyokimyasal ve gerilme mukavemeti karakterizasyonuna tabi tutulmuş, ardından ilaç salımı çalıșması yapılmıștır. Deriye nüfuz etme ve tahriş çalıșması, Wistar Albino sıçanlarında in vivo koşullarda gerçekleştirilmiştir.

Bulgular: Oluşturulan MN dizileri, 0,9 mm uzunluğunda, tabanda $600 \mu \mathrm{m}$ genişliğinde, uçta 30-60 $\mu \mathrm{m}$ çapında ve 2 iğne arasında 1,5 mm mesafeli MN'ler içerir. Bu MN yaması, iyi mekanik mukavemete (0,72 N/iğne) ve 15,23 Mpa gerilme mukavemetine sahipti. MN dizisi yaması, 50. saatte \%6,26 şişme indeksine sahipti ve \%98,5 ilaç salımı gözlendi. Optimize edilmiş MN grubu için iyi penetrasyon elde edilirken ve deri tahrişi gözlenmedi.

Sonuç: Polimerik MN dizileri, arı balmumu kalıbı kullanılarak başarılı bir şekilde geliştirildi ve BSA'yı deri epidermisi katmanından iletmek için başarıyla PLA ile kaplandı.

Anahtar kelimeler: Mikroiğneler, transdermal ilaç dağıtımı, kaplanmış mikroiğneler, mikroiğneli kalıp, balmumu, polilaktik asit

\footnotetext{
*Correspondence: ravindra.badhe@dypvp.edu.in, Phone: 9422432038, ORCID-ID: orcid.org/0000-0002-9919-8154

Received: 31.03.2020, Accepted: 01.09.2020

๑Turk J Pharm Sci, Published by Galenos Publishing House.
} 


\section{INTRODUCTION}

Microneedles (MNs) are structures, which are up to $2 \mathrm{~mm}$ in length, with thickness in few microns. MNs pierce the skin without pain and deliver drugs on the epidermis. MNs allow delivery of hydrophilic and lipophilic drugs and macro molecular therapeutics through the micro channels that are physically formed by the MN, while disrupting the stratum corneum. MNs do not produce pain because they enter the dermis layer without stimulating the sensory nerves. ${ }^{1}$ The first generations of MNs were prepared from metals, organic polymers, glass, silicones as they were used to create micropores into the skin to facilitate drug, vaccine, or protein diffusion in the skin. ${ }^{2}$ The first patent on MNs-based drug delivery was filed in US in 1971. At that time, MNs were referred to as "puncturing projections". However, the first successful attempt of MNs development was in the 1990s, as silicon MNs successfully facilitated the delivery of calcein through the human skin. MNs have shown effectiveness in delivering many therapeutic molecules through biological membranes, including sclera, skin, and mucosal tissue. ${ }^{3,4} \mathrm{MNs}$ arrays are based on combining advantages of the non-invasive and invasive systems and the elimination of their drawbacks. ${ }^{5}$ Solid MNs show the increase in skin permeability for the compounds with size ranging from small molecules to larger molecules, as with proteins to nanoparticles. ${ }^{6-9}$ The successful delivery of insulin ${ }^{10}$ oligonucleotides, desmopressin, human growth hormone,11-13 and the immune response from transportation of DNA and protein antigens..$^{14,15}$ Most MNs reported were prepared from silicon ${ }^{16,17}$ or metal. ${ }^{18,19}$ Silicon is mostly used as a common microelectronics industry substrate, but it is costly, fragile, and is an untested biocompatible material. There are many metals that are cost effective, possess good strength, and known to be biocompatible, ${ }^{20}$ which are the preferred choice for hollow MNs, as it needs good mechanical strength. Research on polymer MNs is recently being explored extensively, as they provide inexpensive and biocompatible materials that offer good strength due to polymer viscoelasticity. ${ }^{21-23}$ In addition, earlier MN fabrication methods were expensive and time consuming because of the clean room-intensive process. ${ }^{24}$

As an innovative approach of MN fabrication, this study aimed to formulate MNs patch using biodegradable polymers and recyclable mould-based fabrication methods. The polymeric MNs are cost effective, biologically safe, have novel features (such as biocompatibility, dissolvable, swellable, and biodegradable), without cross contamination, and precise in large scale production; and have therefore gained importance in recent times. Dissolvable MNs were also reported and they were well-known to be prepared from many biocompatible materials, such as the biopolymer hyaluronic acid. Generally, the popular polymers used in fabrication of MNs are carboxymethyl cellulose, hydroxy propyl cellulose, polylactic acid (PLA), polyglycolic acid, poly lactic-co-glycolic acid, and poly (vinyl) alcohol, poly- vinylpyrrolidone. ${ }^{25-29}$ In this study, PLA-coated chitosan MN array patches were prepared using novel wax-based mould fabrication. The MNs were tested for their mechanical, physicochemical, release of medicament, and swelling properties. The wax-based mould provides a unique advantage of melting and refabricating a mould multiple times to precisely develop reproducible $M N .^{30,31}$

\section{MATERIALS AND METHODS}

\section{Materials}

Chitosan (MW: 190-310 kDa, degree of deacetylation: 85\%), bovine serum albumin (BSA), dichloromethane, acetic acid, and bees wax (MP $63^{\circ} \mathrm{C}$ ) were purchased from High Media, Dorset, UK. Phosphate buffer saline (PBS) solution was obtained from Fischer scientific. PLA (MW: 60 kDA) was procured from Sigma-Aldrich, Darmstadt, Germany. All chemicals used in this study were of analytical grade. MN roller was purchased from ZGTS Derma Roller ${ }^{\circledR}(1 \mathrm{~mm})$, Medsorimpex, sewak park, New Delhi.

\section{Preparation of mould}

Wax-based mould is a simple, economic, less time consuming, and innovative technique to prepare MNs. In this technique, the MN moulds were developed using a bee's wax. The bee's wax (MP: $63^{\circ} \mathrm{C}$ ) was melted and mixed. The liquid wax preparation was poured into a Petri plate and allowed to cool and solidify at room temperature. ${ }^{32}$ The array was prepared by impressing the Derma Roller ${ }^{\circledR}(1 \mathrm{~mm}$ needle length) on the surface of the solidified wax. The prepared wax mould was placed in a vacuum oven at $(-500 \mathrm{mmHg})$ for $20 \mathrm{~min}$ at $\left(37^{\circ} \mathrm{C}\right)$ for removal of dust particles and wax debris.

\section{Fabrication of MN patch}

The $0.5 \%-3 \% \mathrm{w} / \mathrm{v}$ chitosan dissolved in $1 \% \mathrm{v} / \mathrm{v}$ acetic acid solution was used for fabrication of MNs. The prepared gel was rested overnight and spread over the prepared MN wax mould uniformly. Before the spread, care was taken to avoid formation of air bubbles. After few minutes, the MN array was placed in a vacuum oven for 1 day at $37^{\circ} \mathrm{C}$ and $-550 \mathrm{mmHg}$. After completion of the 1-day period, the MN array mould was removed from the oven and the air bubbles generated were scrapped using a glass rod and dried for another 1 day at room temperature. After drying, the MNs patches were pulled out of the wax mould and dried in a hot air oven at $70^{\circ} \mathrm{C}$ for $5 \mathrm{hrs}$. After complete drying of the MNs, the coating was done with PLA solution prepared by dissolving $500 \mathrm{mg}$ of PLA in $5 \mathrm{~mL}$ of dichloromethane. The MN patch was dipped 20 times in the PLA solution until complete coating. ${ }^{33}$ After PLA coating, whole $\mathrm{MN}$ patch was dried at $60^{\circ} \mathrm{C}$ to completely remove the traces of dichloromethane. This PLA-coated chitosan MN patch was again coated with BSA by dipping 20 times in $10 \mathrm{mg} / \mathrm{mL}$ BSA solution (BSA was used as a representative protein for macromolecules). The $M N$ patches were prepared in several batches ( $A$ to $G$ batches), as shown in (Table 1).

\section{Characterization of optimized MN array patch}

Physical examination of MN array by microscope and scanning electron microscopy (SEM)

MN arrays were observed under compound microscope for preliminary morphological examination. MN arrays were initially 
mounted on circular disc and morphologically characterized by SEM (Hitachi S-2460N, Germany) in a high vacuum using Everhart Thornley detector at $10^{-5}$ Torr and $15 \mathrm{kV}$. Each sample was coated with gold using K550 Emitech Sputter coater (Gatan Inc., Pleasanton, CA). A computer software (XT Microscope control, Quanta Oregon, USA) was used to analyze the SEM images. $^{34}$

\section{Mechanical testing of MNs arrays}

\section{Mechanical strength of MNs}

Mechanical strength of MN was studied with a displacement force test station (Model 921A, Tricor Systems Inc., Elgin, IL, USA). MN array ( $1 \times 3 \mathrm{~cm}$ with $108 \mathrm{MN}$ ) was attached to the mount and an axial force was applied at a rate of $1 \mathrm{~mm} / \mathrm{s}$. The MN array was mounted against a flat, rigid surface perpendicular to the axis of the mount movement. The test station measured the compression force needed to move the mount as a function of distance. The study was done in triplicate $(n=3)$.

Tensile strength of MN arrays

Tensile strength of MN arrays was determined using a texture analyzer (TA.XT plus, Stable Micro System, United Kingdom).
The tensile strength was determined based on maximum load at the time of film rupture. Three strips of MN array were cut $(1 \times 5 \mathrm{~cm})$ and used for this test. The thickness and breadth of strips were checked and noted at three different sites and the average value was taken for calculation. The study was done in triplicate $(n=3)$.

Tensile strength $(\mathrm{MPa})=\frac{(\text { Load at break in } \mathrm{gm}) \times 100}{\text { (Original width in } \mathrm{mm}) \text { (Original thickness in } \mathrm{mm})}$

\section{Physicochemical characterization of MNs array}

Determination of standard and released BSA from MN array by SDS-PAGE

SDS-PAGE was used for determination of standard BSA (66 kD) and BSA released from MN array from Franz diffusion cell, according to the method described by Badhe et al. ${ }^{35}$ The resolving gel used was $9 \%$ and staining was done with Coomassie brilliant blue stain.

\section{Determination of chemical integrity of MNs}

Fourier-transform infrared spectroscopy (FTIR) absorption spectrum of Chitosan, PLA, BSA, and BSA coated on PLA-coated

Table 1. MN batches prepared on the wax mould

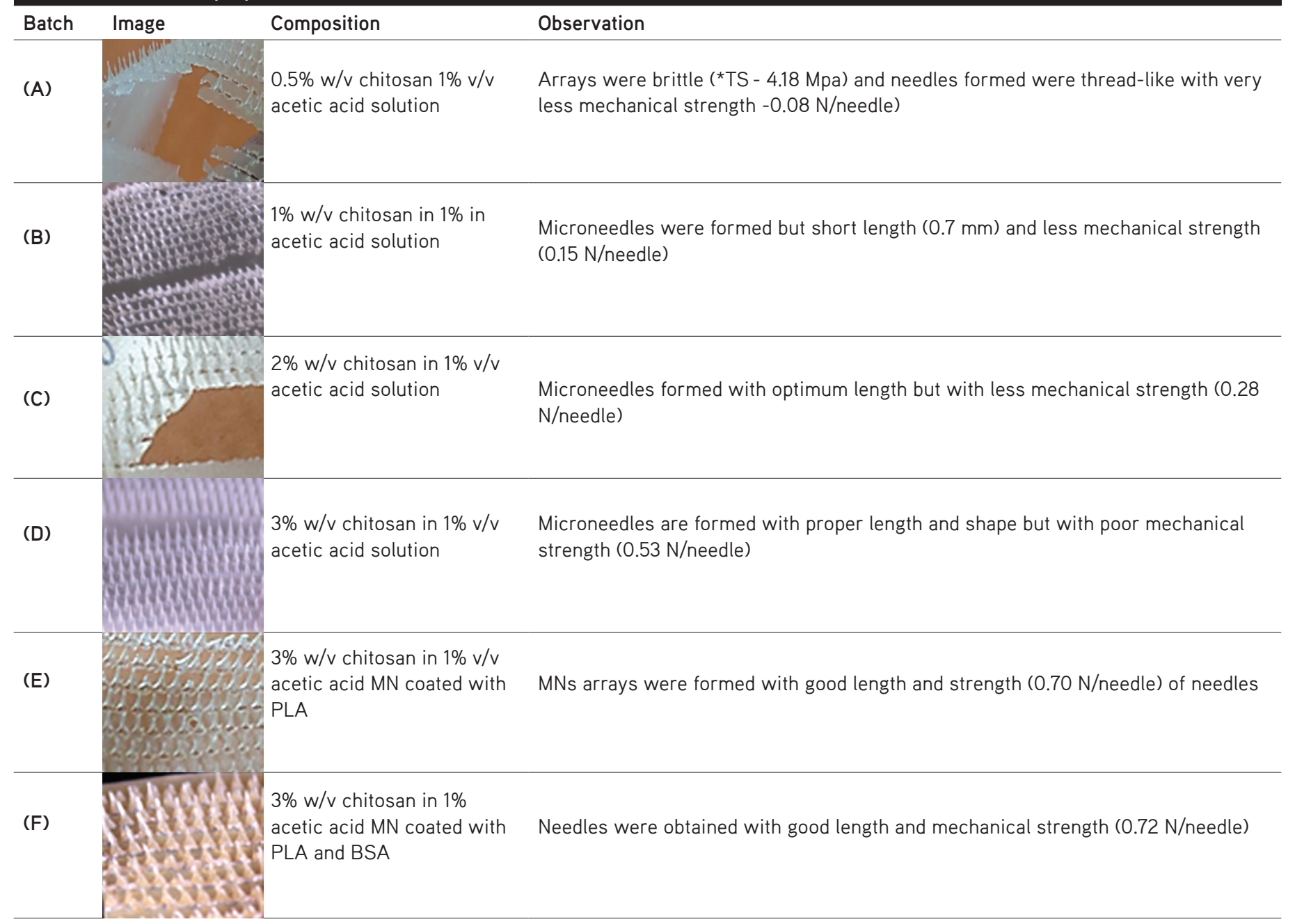

*TS: Tensile strength, MN: Microneedle, PLA: Polylactic acid, BSA: Bovine serum albumin 
chitosan MN was analyzed using a FTIR spectrophotometer (8400S Shimadzu, Japan) over the range 4000-600 $\mathrm{cm}^{-1}$. The baseline correction was performed using dried potassium bromide. Subsequently, the spectrum of mixture of analyte and potassium bromide was recorded and the peaks belonging to major functional groups were recorded.

\section{Thermodynamic evaluation of MNs arrays}

Differential scanning calorimetry (DSC) analysis was performed for Chitosan, PLA, PLA-coated chitosan MN, and BSA coated on PLA-coated chitosan MN array using DSC7 (PerkinElmer, Germany). Sample weights were taken in the range of 5-10 $\mathrm{mg}$. All samples were analyzed in scanning mode from $25^{\circ} \mathrm{C}$ to $350^{\circ} \mathrm{C}$ at a heating rate of $10^{\circ} \mathrm{C} / \mathrm{min}$. Dry nitrogen gas was purged in during the DSC analysis.

\section{Evaluation of the degree of crystallinity}

X-ray diffraction (XRD) spectra for chitosan, PLA, and BSA coated on PLA-coated chitosan MN arrays were recorded using Brucker D8 Advanced X-ray diffractometer (PDXL2 software, Tokyo, Japan) using $\mathrm{Cu} \mathrm{K} 2 \alpha$ rays at a voltage of $40 \mathrm{kV}$ and current of $25 \mathrm{~mA}$. Samples were scanned at the rate of $2^{\circ} \theta$ from 10 to $60^{\circ} \theta$.

\section{Determination of viscosity of wax mixture}

A Rheometer (RVDV-II, Brookfield, USA) was used to study the viscosity of wax and chitosan gel. The temperature control was achieved using heated plate, allowing the gradual increase of temperature from $20^{\circ} \mathrm{C}$ to $80^{\circ} \mathrm{C}$.

\section{Determination of swelling index of MNs array}

A MN patch of $1 \mathrm{~cm}^{2}$ (36 MN) size from the optimized batch was weighed and placed on a pre-weighed cover slip. It was placed in a petridish and $10 \mathrm{~mL}$ of distilled water was added. After $10 \mathrm{~min}$, the cover slip was removed and excess water was wiped off carefully using a tissue paper and weighed. Weight increase due to absorption of water and swelling of patch was determined by calculating the difference between initial and final weight.

The percentage swelling index was calculated using the following equation (2):

$\%$ Swelling index $=(\mathrm{Wt}-$ Wo $/$ Wo $) \times 100$

Where Wt is the final weight of the swollen film after time t, Wo is the initial weight of the film at zero time. Due to scarcity of the optimized sample, statistical analysis was not performed.

\section{$B S A$ release study from microneedle array}

Standard calibration curve of BSA was prepared by dissolving $10 \mathrm{mg}$ of BSA in $100 \mathrm{~mL}$ PBS buffer ( $\mathrm{pH} 7.4$ ) to yield $100 \mu \mathrm{g} / \mathrm{mL}$ stock solution. From the stock solution, serial dilutions were made: $2,4,6,8,10,20,30,40$, and $50 \mu \mathrm{g} / \mathrm{mL}$ with PBS ( $\mathrm{pH} 7.4$ ). From each dilution, $1 \mathrm{~mL}$ of the solution was pipetted out and 2 drops of biuret reagent was added, followed by dilution of the solution up to $3 \mathrm{~mL}$ with PBS. The reaction of BSA with biuret reagent generates a pink or purple coloration, which is observed and analyzed in a ultraviolet-visible spectrophotometer
(Shimadzu, Japan 1700) against PBS as blank at $540 \mathrm{~nm} \lambda_{\text {max }}$. The absorbance values obtained were used to prepare the standard calibration curve of BSA.

The drug release studies of BSA-coated MN arrays were performed with Franz diffusion cell apparatus using $45 \mathrm{~mL}$ of PBS ( $\mathrm{pH} 7.4$ ) as a dissolution medium at $37^{\circ} \mathrm{C} \pm 0.5^{\circ} \mathrm{C}$. The speed of the magnetic stirrer was adjusted to $100 \mathrm{rpm}$. The MN arrays were inserted into the shaved rat skin fixed to the receiver compartment. From this compartment, $1 \mathrm{~mL}$ of the medium was collected at a specific time interval and analyzed for BSA content, following the same protocol (biuret test) used for preparing the BSA standard calibration curve. An equivalent volume $(1 \mathrm{~mL})$ of the fresh PBS was added to Franz diffusion cell apparatus each time to make up the loss due to sampling. Due to scarcity of the optimized sample, statistical analysis was not performed.

\section{Skin irritation study}

Skin irritation study of MNs arrays was performed to determine whether the prepared MN arrays can cause any irritation to the rat's skin (Animal Ethical Committee approval no DYPIPSR/ IAEC/Nov./18-19/P-09). MN arrays (1 cm x $3 \mathrm{~cm}$ ) were applied using gentle pressure to shaved back skin of Wistar Albino rats (180-220 gm) and secured for $24 \mathrm{hrs}$ with a medical adhesive tape. After $24 \mathrm{hrs}, \mathrm{MN}$ arrays were removed and the rats were monitored for any sign of irritation on the rat's skin or any other adverse effect. The test site was analyzed for 7 days after removal of the MN. As the study involves only visual inspection of any reaction, no statistical evaluation was performed.

\section{RESULTS AND DISCUSSION}

\section{Fabrication of wax mould}

The bees wax was melted at $63^{\circ} \mathrm{C}$ and allowed to settle in petridish for 30 min. The impression of Derma Roller ${ }^{\circledR}(1 \mathrm{~mm}$ needle length) was easily done to obtain the MN mould. For fabrication of MNs, four different concentrations of chitosan were used. The various batches that were tried are given in Table 1, Figure 1.

\section{Optimization batches of MN patch}

The optimized batch (batch D) was selected as $3 \% \mathrm{w} / \mathrm{v}$ chitosan prepared in $1 \% \mathrm{v} / \mathrm{v}$ acetic acid solution based on the mechanical strength and morphology of MNs (Table 1). This optimized batch was further coated with PLA (batch E), followed by BSA (batch F). ${ }^{36-39}$

\section{Physical characterization of $M N$}

\section{Physical examination of MN array using SEM}

\section{SEM}

The normal and SEM images of plain chitosan MN, PLA-coated chitosan MN, and BSA coated on PLA-coated MN arrays are shown in (Figure 2). It can be clearly observed that $0.5 \%$ chitosan MN appear thread-like and has very less mechanical strength (Figure 2a). However, 3\% chitosan MN are formed nicely, but with a porous structure inside (Figure $2 b$ ). When these $3 \%$ chitosan MNs were coated with PLA, the MN became 
stronger with improved mechanical strength (Figure 2c) and Figure $2 \mathrm{~d}$ suggests the uniform coating of BSA over PLA coat. ${ }^{40}$ Moreover, the SEM images suggest that MNs are $0.9 \mathrm{~mm}$ in height, $600 \mu \mathrm{m}$ in width at base, and 30-60 $\mu \mathrm{m}$ at the tip diameter and that the distance between $2 \mathrm{MN}$ was $1.5 \mathrm{~mm} .{ }^{41}$

\section{Mechanical strength of MNs arrays}

Mechanical strength of MN needs must be sufficient to sustain the force applied during pressing of MN array patch into the skin. ${ }^{42}$ This insertion compression force might lead to bending or breaking of MNs. The reported mechanical strength for
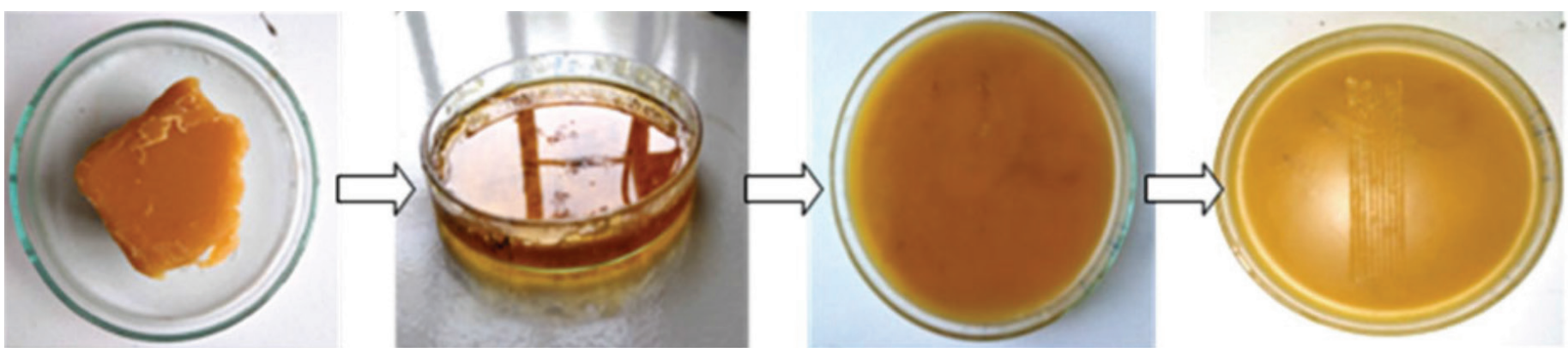

Figure 1. Fabrication of wax-based $M N$ array mould MN: Microneedle
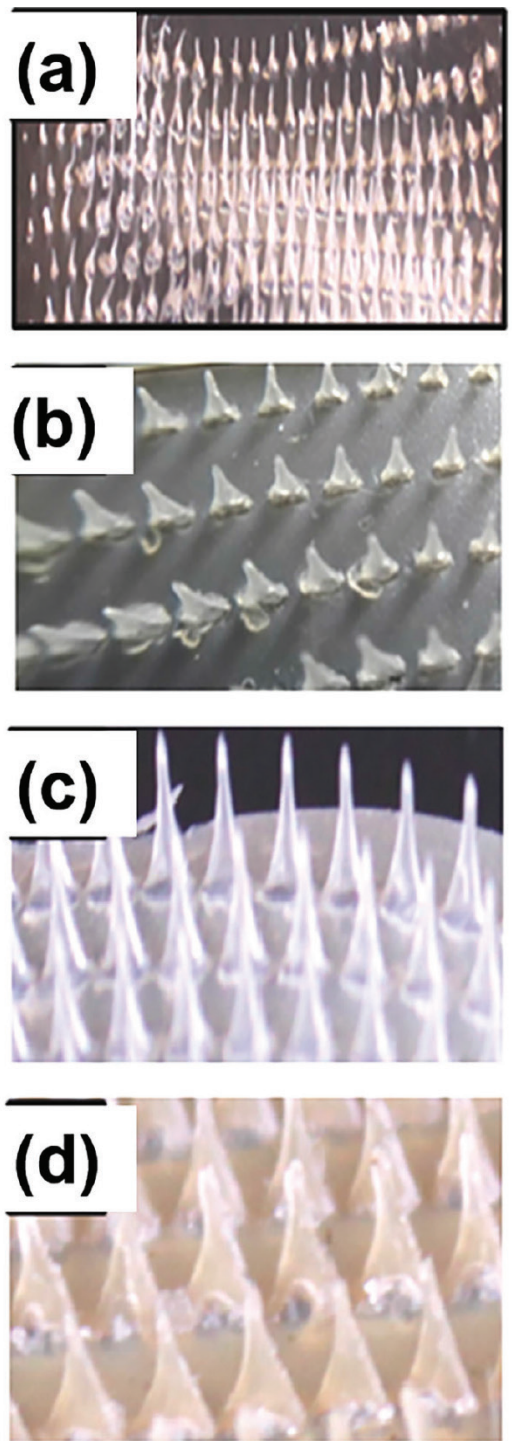
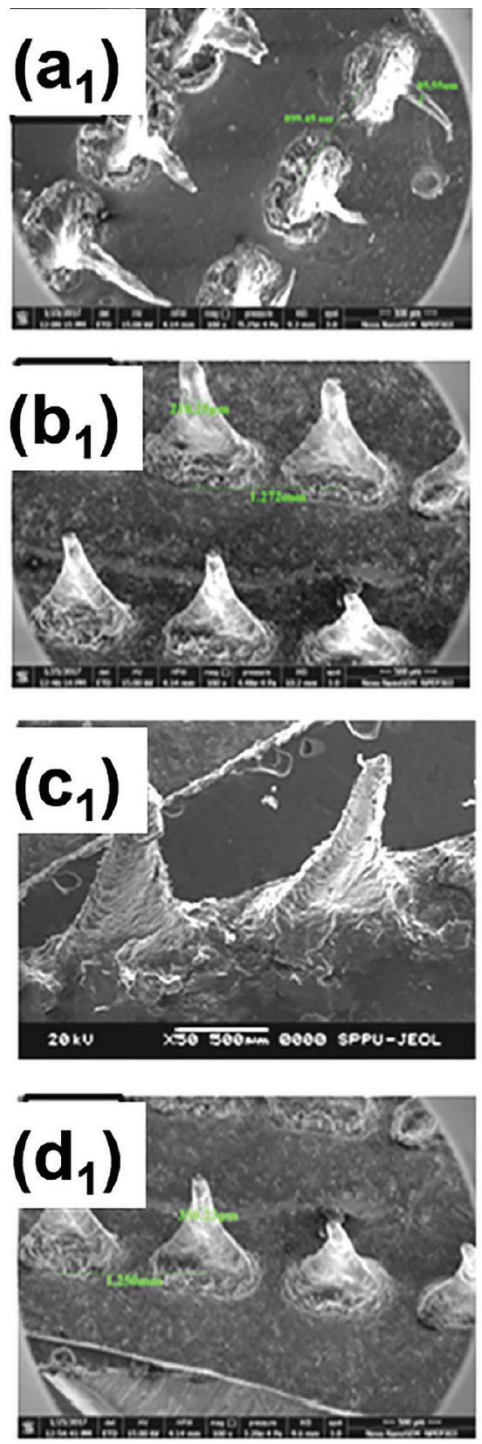
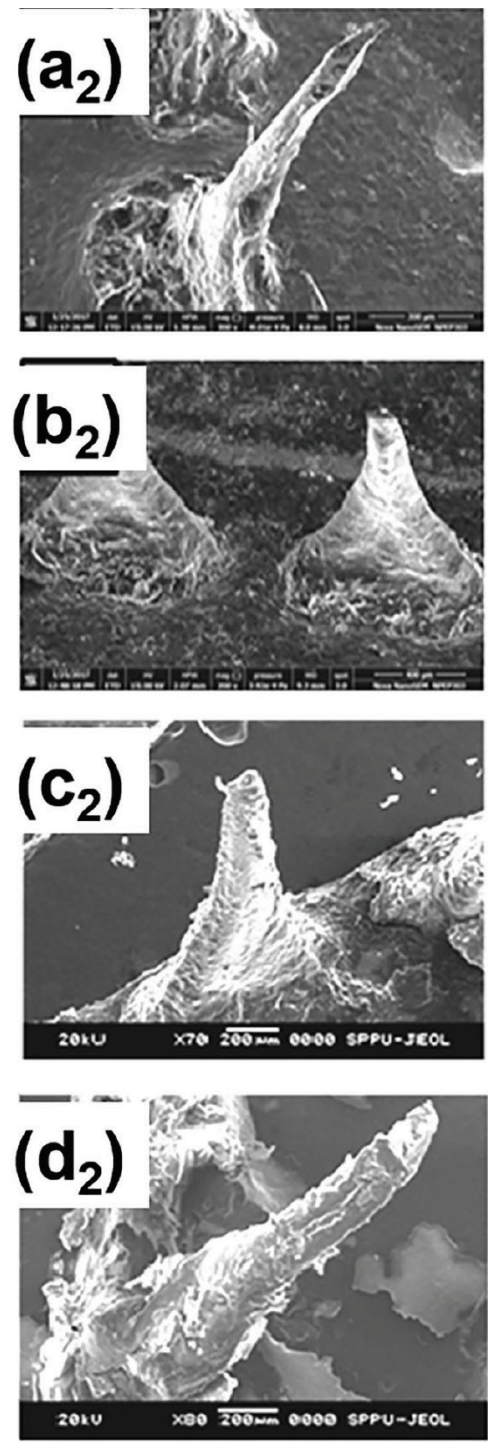

Figure 2. SEM images of $\left(a, a_{1}\right.$, and $\left.a_{2}\right)$ 0.5_ chitosan MN (b, $b_{1}$, and $\left.b_{2}\right) 3_{-}$chitosan MN (c, $c_{1}$, and $\left.c_{2}\right)$ PLA-coated chitosan MN ( $d_{\text {, }} d_{1}$, and $\left.d_{2}\right)$, and BSA coated on PLA-coated chitosan MN array

SEM: Scanning electron microscopy, MN: Microneedle, PLA: Polylactic acid, BSA: Bovine serum albumin 
efficient chitosan MNs was $0.50 \mathrm{~N} /$ needle. $^{43}$ and the mechanical strength of BSA and PLA-coated chitosan MN was $0.72 \mathrm{~N} /$ needle.

\section{Tensile strength of MNs arrays}

Tensile strength of MN arrays is an important property, since it defines the integrity of the patch and capacity of the patch to survive the physical stress. The previously reported tensile strength for chitosan film is $11.23 \mathrm{Mpa}^{44}$ and that of BSA and PLA-coated MN array patch shows 15.23 Mpa.

\section{Spectral and thermal analysis of MNs arrays}

\section{FTIR spectroscopy}

The FTIR spectrum of chitosan (Figure 3a) showed important bands of the characteristics functional groups, which were recorded in the infrared range $\left(4000-6000 \mathrm{~cm}^{-}\right.$ $\left.{ }^{1}\right)$. The infrared spectra for chitosan showed a stretching vibration band at $3419.42 \mathrm{~cm}^{-1}$ for $\mathrm{OH}$ group and 1064.79 $\mathrm{cm}^{-1}$ for $-\mathrm{C}-\mathrm{O}$ of $\mathrm{CH}_{2} \mathrm{OH}$ group. The spectra also showed $\mathrm{NH}$ bend at $1643.41 \mathrm{~cm}^{-1}$ and $\mathrm{NH}$ stretch at $3354.15 \mathrm{~cm}^{-1}$ for amine group. FTIR spectra of PLA (Figure $3 \mathrm{~b}$ ) showed 2839.73 $\mathrm{cm}^{-1}$ and $2910.68 \mathrm{~cm}^{-1}$ for $\mathrm{C}-\mathrm{H}$ stretch and $1491.02 \mathrm{~cm}^{-1} \mathrm{C}-\mathrm{H}$ bending vibrations in $\mathrm{CH}_{3}$. Also, $\mathrm{OH}$ stretch at $3464.23 \mathrm{~cm}^{-1}$, $\mathrm{C}=\mathrm{O}$ stretch at $1757.84 \mathrm{~cm}^{-1}$, and $\mathrm{C}-\mathrm{O}-\mathrm{C}$ stretching vibration were observed at $1350.32 \mathrm{~cm}^{-1}$. FTIR spectra of plain BSA (Figure $3 \mathrm{c}$ ) showed $\mathrm{C}=\mathrm{O}$ stretch vibrations of the peptide linkages at $1667.21 \mathrm{~cm}^{-1}, \mathrm{~N}-\mathrm{H}$ bending vibration for amide II at $1537.91 \mathrm{~cm}^{-1}$, and $\mathrm{N}-\mathrm{H}$ bending vibration at $3292.60 \mathrm{~cm}^{-1}$. FTIR spectra of BSA and PLA-coated chitosan MN (Figure 3d) showed all the characteristic peak of chitosan, such as $\mathrm{NH}$ bend (amine) at $1635.41 \mathrm{~cm}^{-1}$ and $\mathrm{NH}$ stretch at 3249.20 $\mathrm{cm}^{-1}, 2930.93 \mathrm{~cm}^{-1}$ for $\mathrm{C}-\mathrm{H}$ stretch and $1498.74 \mathrm{~cm}^{-1} \mathrm{C}-\mathrm{H}$ bending vibrations in $\mathrm{CH}_{3}$ for PLA and BSA, $\mathrm{N}-\mathrm{H}$ bending

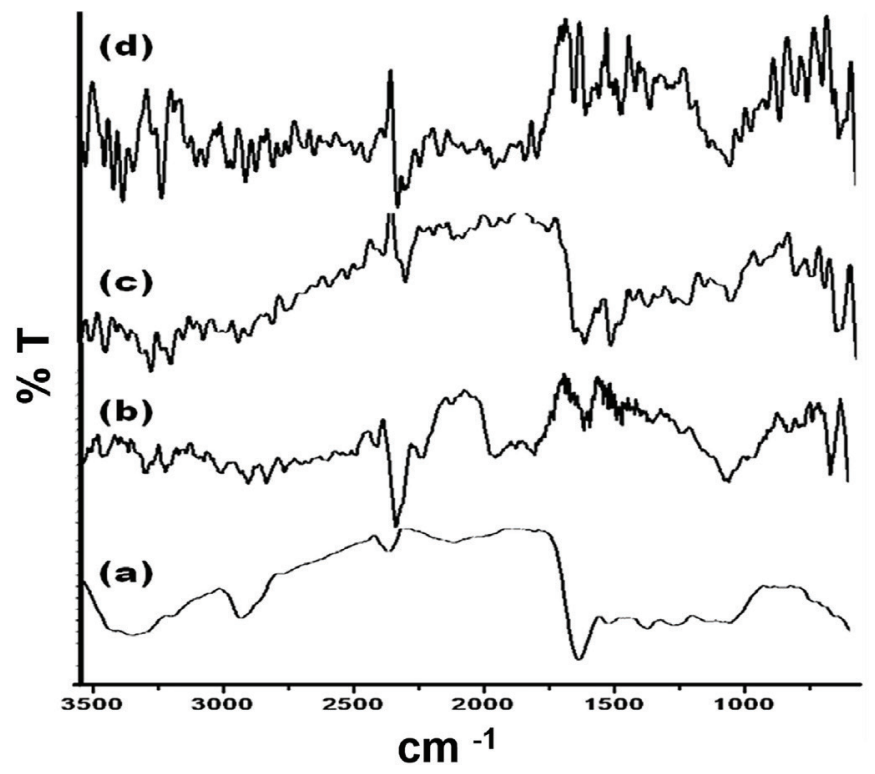

Figure 3. FTIR spectra of a) chitosan b) PLA c) BSA, and d) BSA coated on PLA-coated chitosan MN array

FTIR: Fourier-transform infrared spectroscopy, PLA: Polylactic acid, MN: Microneedle, BSA: Bovine serum albumin vibration for amide II at $1525.74 \mathrm{~cm}^{-1}$, and C-N stretching/ bending vibration at $1166.97 \mathrm{~cm}^{-1} / 2330.34 \mathrm{~cm}^{-1}$ for BSA. Thus, all the molecules retained their functional group and no interaction was observed between them.

\section{Thermal analysis of MN array}

DSC thermogram of PLA (Figure 4a) shows endothermic peaks at $56^{\circ} \mathrm{C}$ and $105^{\circ} \mathrm{C}$, which are related to glass transition (GT) and moisture loss, as well as broad endothermic peak at $170^{\circ} \mathrm{C}$, followed by broad exothermic peak at $220^{\circ} \mathrm{C}$ (melting), followed by degradation of PLA. These values match closely with previously reported value. ${ }^{45}$ DSC thermogram of Chitosan (Figure 4b) shows endothermic peak at $90^{\circ} \mathrm{C}$, which is related to moisture loss, endothermic peak at $240^{\circ} \mathrm{C}$, followed by exothermic peak at $280^{\circ} \mathrm{C}$, which corresponds to the degradation of chitosan. These values match closely with previously reported values. ${ }^{46}$ The DSC thermogram of PLAcoated chitosan MN (Figure 4c) shows small endothermic peak at $60^{\circ} \mathrm{C}$ for GT of PLA, endothermic peak of water loss at $100^{\circ} \mathrm{C}$, and endothermic peak at $230^{\circ} \mathrm{C}$, followed by exothermic peak at $270^{\circ} \mathrm{C}$, which represents the degradation of PLA and chitosan, respectively. The DSC thermogram of BSA and PLA-coated MN (Figure 4d) shows a short endothermic peak for GT of PLA at $63^{\circ} \mathrm{C}$ and a short endothermic peak at $100^{\circ} \mathrm{C}$, which is related to water loss and degradation of BSA. It also shows a small exothermic peak at $215^{\circ} \mathrm{C}$ corresponding to the degradation of $\mathrm{PLA}$ and a broad endothermic peak at $215^{\circ} \mathrm{C}$, followed by $260^{\circ} \mathrm{C}$ broad exothermic peak corresponding to chitosan and PLA degradation.

\section{$X R D$ spectral analysis}

The diffractogram of chitosan shows sharp peak at $22^{\circ} \theta$, $26.5^{\circ} \theta$, and $33^{\circ} \theta$ and the broad peak shows chitosan slightly

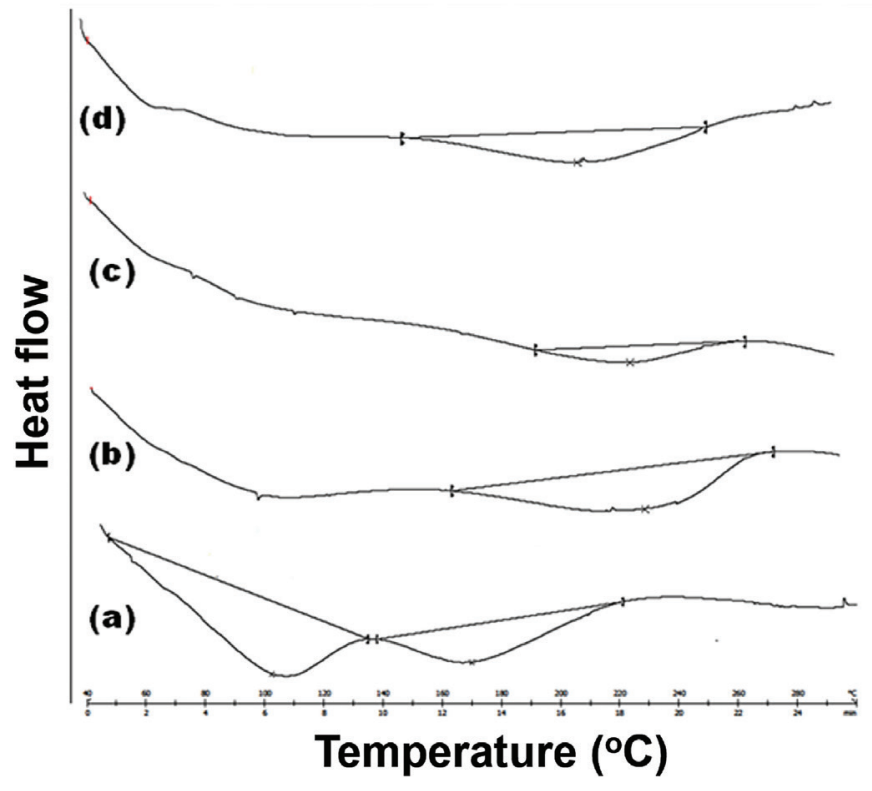

Figure 4. DSC thermogram of a) PLA b) chitosan c) PLA-coated chitosan MN d) BSA coated on PLA-coated chitosan MN array

DSC: Differential scanning calorimetry, PLA: Polylactic acid, MN: Microneedle, BSA: Bovine serum albumin 
crystalline in nature (Figure 5a). These observations match with previous reports. ${ }^{21,46}$ The diffractogram of PLA shows a broad peak at $16.55^{\circ} \theta$ and $30^{\circ} \theta$. It suggests that PLA used in this study is amorphous in nature (Figure $5 \mathrm{~b}$ ) this observation match with reported value ${ }^{47}$ and supports the DSC data, which lacks sharp endothermic peak of GT temperature at $60^{\circ} \mathrm{C}$. The diffractogram of BSA coated on PLA-coated chitosan MN array batch (Figure $5 \mathrm{c}$ ) showed sharp peak at $22^{\circ} \theta, 24^{\circ} \Theta$, and $32^{\circ} \theta$, emerging from a broad peak corresponding to chitosan and broadness of the overall diffractogram corresponding to PLA, which suggests that coating of chitosan MN does not hamper crystallinity to the $\mathrm{MN}$ array. This is an important observation, as it explains the improved mechanical properties of the MN array.

\section{Drug release profile of optimized batch}

The in vitro drug release study was performed in order to ensure a release of drug in selected dissolution medium. The drug release profile was determined in PBS $(\mathrm{pH} \mathrm{7.4)}$ and $98.5 \%$ BSA was released within 50 hours from the rat skin (Figure 6). ${ }^{48}$

\section{Determination of viscosity of wax and gel}

The change of viscosity with increasing temperature gradient was performed for bee's wax and chitosan gel. The viscosity decreased with increase in temperature. Thus, both gel and wax come under the Newtonian flow behavior.

\section{Swelling index of MNs arrays}

Figure 7 shows the swelling behavior of the BSA and PLAcoated MN array. It was observed that the maximum swelling of $6.79 \%$ was observed at 30 minutes. The weight decreased after 30 min might be due to the dissolution of BSA.

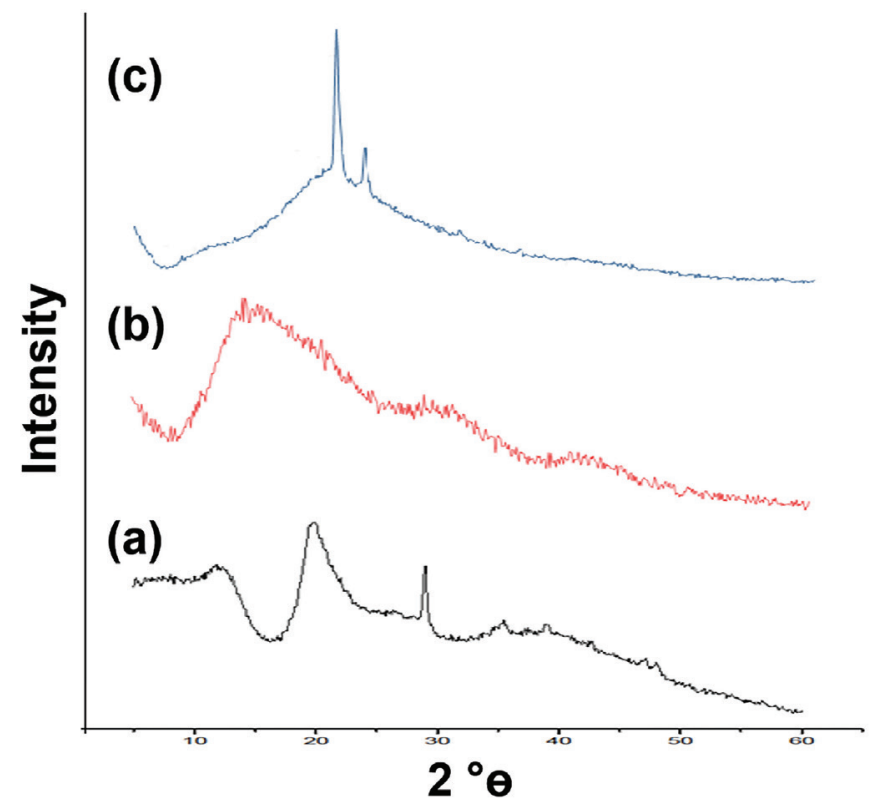

Figure 5. XRD spectral analysis of a) chitosan b) PLA c) BSA coated on PLA-coated chitosan MN array

XRD: X-ray diffraction, PLA: Polylactic acid, MN: Microneedle, BSA: Bovine serum albumin

\section{In vivo tolerance study}

After removal of MN and careful observation for the next 7 days, it was noted that there was no sign of irritation and any adverse effect due to MN (Figure 8).

\section{CONCLUSION}

The successful fabrication of MN was performed using chitosan polymer and bees wax mould. Selected MN batch was subjected to coating with PLA and BSA, followed by morphological, mechanical, and drug release studies. Based on SEM characterization of MN formulation; the coated MNs had $0.9 \mathrm{~mm}$ length, $600 \mu \mathrm{m}$ width at the base, $1.5 \mathrm{~mm}$ distance between 2 needles, and 30-60 um tip diameter. The optimized MN batch showed the percentage BSA release of $98.5 \%$ in 50 hours. It also showed good mechanical strength $(0.72 \mathrm{~N} /$ needle), tensile strength (15.23 Mpa) and maximum swelling of $6.79 \%$.

The results obtained from various studies performed for PLAand BSA-coated-layered chitosan MNs possessed desired mechanical strength, tensile strength, swelling index, and drug release. SEM, XRD, and DSC studies established the physicochemical properties of MN.

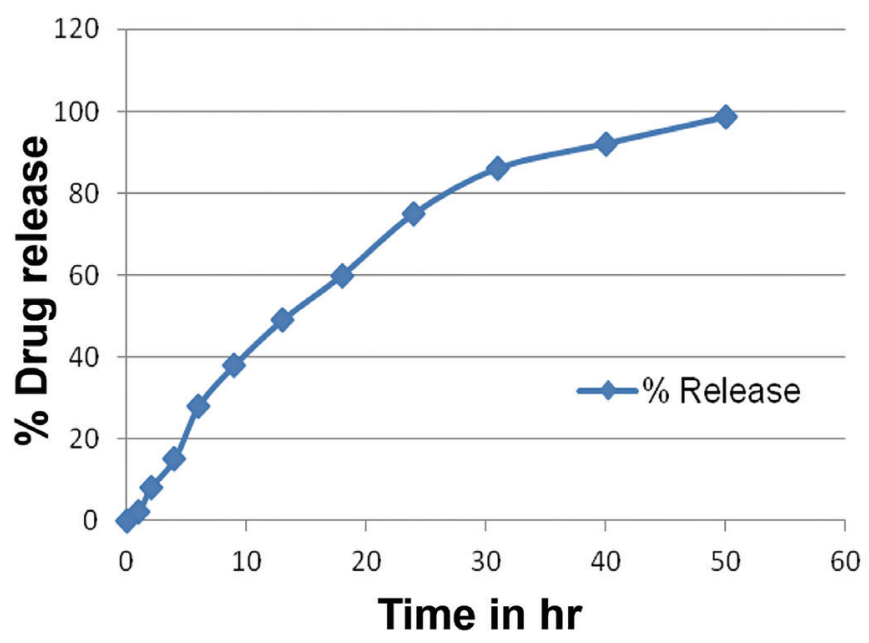

Figure 6. Drug release of optimized batch

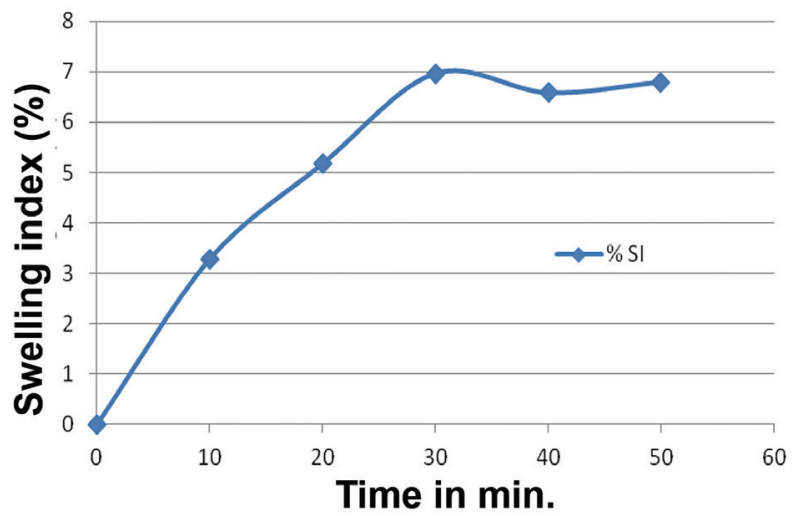

Figure 7. Swelling index of BSA and PLA-coated MN array PLA: Polylactic acid, MN: Microneedle, BSA: Bovine serum albumin, SI: Swelling index 

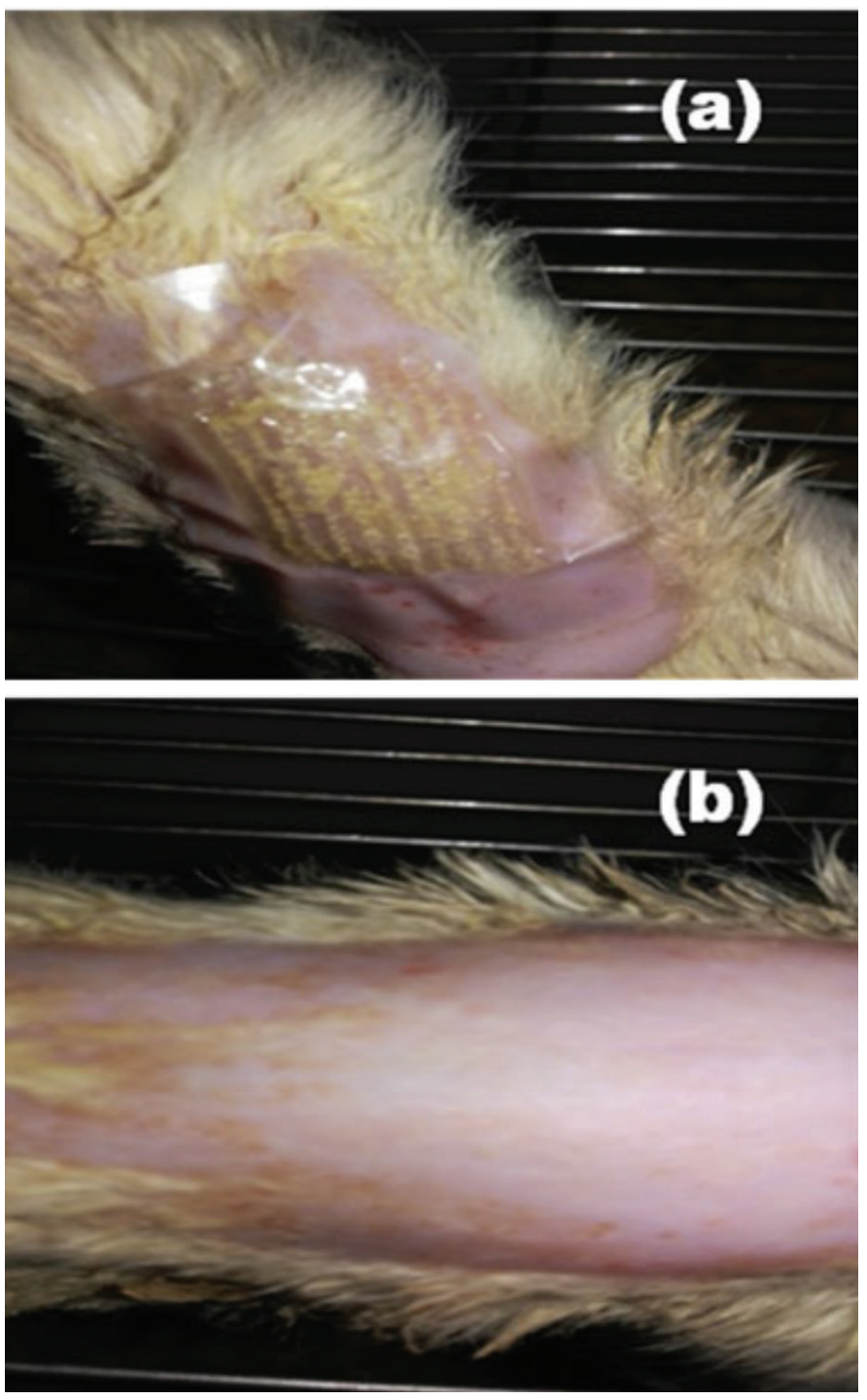

Figure 8. Skin irritation study a) microneedle array patch inserted in the dorsal skin of rat, b) dorsal skin of rat after seven days of MN array patch removal

MN: Microneedle

Thus, it is concluded that the study of fabrication of novel waxbased mould (which can be melted and re-casted multiple times) and development of BSA and PLA-coated chitosan MN was successfully attempted. The MN patches easily pierced the skin with gentle application of force. It showed significant amount of drug release into the dermis. Furthermore, it is proposed that the wax-based mould technique for the development of MN patch and the developed coated polymeric MNs can be tested for its drugs, macromolecules, and vaccines delivery potential, as a pain less and effective drug delivery system.

The same MN arrays can act as a time-controlled delivery system, since porous chitosan will be exposed after the dissolution of two layers (BSA and PLA). Thus, chitosan MN can be loaded with the drugs to be released after a particular time. Even PLA can be doped with certain medicament to obtain sustained drug delivery after dissolution of the BSA layer. BSA can be substituted with vaccines or DNA/RNA to achieve the immediate release. Thus, each layer of MN will provide the platform for a time-bound drug delivery system.

Conflicts of interest: No conflict of interest was declared by the authors. The authors alone are responsible for the content and writing of the paper.

\section{REFERENCES}

1. Gualeni B, Coulman SA, Shah D, Eng PF, Ashraf H, Vescovo P, Blayney GJ, Piveteau LD, Guy OJ, Birchall JC. Minimally invasive and targeted therapeutic cell delivery to the skin using microneedle devices. $\mathrm{Br} J$ Dermatol. 2018;178:731-739.

2. Ita K. Transdermal delivery of drugs with microneedles-potential and challenges. Pharmaceutics. 2015;7:90-105.

3. Akhtar NA, Pathak K. Preclinical and clinical aspects of antimicrobial drugs delivered via ethosomal carriers. Antiinfective Ag. 2012;10:15-25.

4. Mishra R, Pramanick B, Maiti TK, Bhattacharyya TK. Glassy carbon microneedles-new transdermal drug delivery device derived from a scalable C-MEMS process. Microsyst Nanoeng. 2018;4:1-11.

5. Hao Y, Li W, Zhou X, Yang F, Qian Z. Microneedles-based transdermal drug delivery systems: a review. J Biomed Nanotechnol. 2017;13:15811597.

6. Mansoor I, Lai J, Lambert D, Dutz J, Häfeli U, Stoeber B. Hollow metallic microneedles for transdermal drug delivery. Trans Jpn Soc Med Biol Eng. 2013;51(Suppl):M-38.

7. Nguyen J, Ita KB, Morra MJ, Popova IE. The influence of solid microneedles on the transdermal delivery of selected antiepileptic drugs. Pharmaceutics. 2016;8:33.

8. Prausnitz MR. Engineering microneedle patches for vaccination and drug delivery to skin. Annu Rev Chem Biomol Eng. 2017;8:177-200.

9. Kim KS, Ita K, Simon L. Modelling of dissolving microneedles for transdermal drug delivery: theoretical and experimental aspects. Eur $\mathrm{J}$ Pharm Sci. 2015;68:137-143.

10. Jin X, Zhu DD, Chen BZ, Ashfaq M, Guo XD. Insulin delivery systems combined with microneedle technology. Send to Adv Drug Deliv Rev. 2018;127:119-137.

11. Jepps OG, Dancik Y, Anissimov YG, Roberts MS. Modeling the human skinbarrier- Towards a better understanding of dermal absorption. Adv Drug Deliv Rev. 2013;65:152-168.

12. Jacoby E, Jarrahian C, Hull HF, Zehrung D. Opportunities and challenges in delivering influenza vaccine by microneedle patch. Vaccine. 2015;33:4699-4704.

13. Ameri M, Kadkhodayan M, Nguyen J, Bravo JA, Su R, Chan K, Samiee A, Daddona PE. Human growth hormone delivery with a microneedle transdermal system: preclinical formulation, stability, delivery and pk of therapeutically relevant doses. Pharmaceutics. 2014;6:220-234.

14. Kwon KM, Lim SM, Choi S, Kim DH, Jin HE, Jee G, Hong KJ, Kim JY. Microneedles: quick and easy delivery methods of vaccines. Clin Exp Vaccine Res. 2017;6:156-159.

15. Huang D, Zhao D, Huang Y, Liang Z, Li Z. Microneedle roller electrode array (M-REA): A new tool for in vivo low-voltage electric gene delivery. In2018 IEEE Micro Electro Mechanical Systems (MEMS). 2018:400403. 
16. Narayanan SP, Raghavan S. Solid silicon microneedles for drug delivery applications. Int J Adv Manuf Tech. 2017;93:407-422.

17. Rouhi N, Jung-Kubiak C, White V, Wilson D, Anderson J, MarreseReading C, Forouhar S. Fabrication of 3-D silicon microneedles using a single-step DRIE process. J Microelectromech Syst. 2015;24:1409-1414.

18. Ullah A, Kim CM, Kim GM. Porous polymer coatings on metal microneedles for enhanced drug delivery. R Soc Open Sci. 2018;5:171609. doi: 10.1098/ rsos.171609.

19. Li J, Liu B, Zhou Y, Chen Z, Jiang L, Yuan W, Liang L. Fabrication of a Ti porous microneedle array by metal injection moulding for transdermal drug delivery. PLOS ONE. 2017;12:e0172043.

20. Larrañeta E, Lutton REM, Woolfson AD, Donnelly RF. Microneedle arrays as transdermal and intradermal drug delivery systems: Materials science, manufacture and commercial development. Mater Sci Eng R Rep. 2016;104:1-32.

21. Badhe RV, Nanda RK, Chejara DR, Choonara YE, Kumar P, du Toit LC, Pillay V. Microwave-assisted facile synthesis of a new tri-block chitosan conjugate with improved mucoadhesion. Carbohydr Polym. 2015;130:213221.

22. Samant PP, Prausnitz MR. Mechanisms of sampling interstitial fluid from skin using a microneedle patch. Proceed Natl Acad Sci. 2018;115:45834588.

23. Wang $M, H u L, X u C$. Recent advances in the design of polymeric microneedles for transdermal drug delivery and biosensing Lab Chip. 2017;17:1373-1387.

24. Nejad HR, Sadeqi A, Kiaee G, Sonkusale S. Low-cost and cleanroom-free fabrication of microneedles. Nat Microsyst Nanoeng. 2018;4:17073.

25. Ono A, Ito S, Sakagami S, Asada H, Saito M, Quan YS, Kamiyama F, Hirobe $\mathrm{S}$, and Okada N. Development of novel faster-dissolving microneedle patches for transcutaneous vaccine delivery. Pharmaceutics. 2017;9:27.

26. Waghule T, Singhvi G, Dubey SK, Pandey MM, Gupta G, Singh M, Dua K. Microneedles: a smart approach and increasing potential for transdermal drug delivery system. Biomed Pharm. 2019;109:1249-1258.

27. Kang G, Tu TN, Kim S, Yang H, Jang M, Jo D, Ryu J, Baek J, Jung H. Adenosine-loaded dissolving microneedle patches to improve skin wrinkles, dermal density, elasticity and hydration. Int J Cosmet Sci. 2018;40:199-206.

28. Naves L, Dhand C, Almeida L, Rajamani L, Ramakrishna S, Soares G. Poly(lactic-co-glycolic) acid drug delivery systems through transdermal pathway: an overview. Prog Biomater. 2017;6:1-11.

29. Vora LK, Vavia PR, Larrañeta E, Bell SEJ, Donnelly RF. Novel nanosuspension-based dissolving microneedle arrays for transdermal delivery of a hydrophobic drug. J Interdiscip Nanomed. 2018;3:89-101.

30. Koen van der M, Sekerdag E, Schipper P, Kersten GFA, Jiskoot W, Bouwstra JA. Layer-by-Layer assembly of inactivated poliovirus and n-trimethyl chitosan on ph-sensitive microneedles for dermal vaccination. Langmuir. 2015;31:8654-8660.

31. Lin YH, Lee IC, Hsu WC, Hsu CH, Chang KP, Gao SS. Rapid fabrication method of a microneedle mold with controllable needle height and width. Biomed Microdevices. 2016;18:85.

32. Fratini F, Cilia G, Turchi B, Felicioli F. Beeswax: a minireview of its antimicrobial activity and its application in medicin. Asian Pac J Trop Med. 2016;9:839-843.
33. Lee K, Lee CY, Jung H. Dissolving microneedles for transdermal drug administration prepared by stepwise controlled drawing of maltose. Biomaterials. 2011;32:3134-3140.

34. Iliescu FS, Teo JC, Vrtacnik D, Taylor H, Iliescu C. Cell therapy using an array of ultrathin hollow microneedles. Microsyst Technol. 2018;24:29052912.

35. Badhe RV, Pradeep Kumar, Choonara YE, Thashree Marimuthu, du Toit LC, Divya Bijukumar, Chejara DR, Mabrouk M, Pillay V. Customized peptide biomaterial synthesis via an environment-reliant auto-programmer stigmergic approach. Materials. 2018;11:609.

36. Chen MC, Ling MH, Lai KY, Pramudityo E. Chitosan microneedle patches for sustained transdermal delivery of macromolecules. Biomacromolecules. 2012;13:4022-4031.

37. Sadeqi A, Nejad HR, Kiaee G, Sonkusale S. Cost-effective Fabrication of Chitosan Microneedles for Transdermal Drug Delivery," $201840^{\text {th }}$ Annual International Conference of the IEEE Engineering in Medicine and Biology Society (EMBC), Honolulu, HI, 2018: 5737-5740.

38. Marin A, Andrianov AK. Carboxymethylcellulos-Chitosan-coated microneedles with modulated hydration properties. J Appl Poly Sci. 2011;121:395-401.

39. Hong X, Wu Z, Chen L, Wu F, Wei L, Yuan W. Hydrogel microneedle arrays for transdermal drug delivery. Nano-Micro Lett. 2014;6:191-199.

40. Olatunji O, Igwe CC, Ahmed AS, Alhassan DO, Asieba GO, Diganta BD. Microneedles from fish scale biopolymer. J Appl Poly Sci. 2014:131:40377.

41. Roxhed N, Gasser TC, Griss P, Holzapfel GA, Stemme G. Penetration enhanced ultra sharp microneedles and prediction on skin interaction for efficient transdermal drug delivery. J Microelectromech Syst. 2007;16:1429-1440.

42. Olatunji O, Das DB, Garland MJ, Belaid L, Donnelly RF. Influence of array interspacing on the force required for successful microneedle skin penetration: Theoretical and practical approaches. J Pharm Sci. 2013;102:1209-1221.

43. Demir YK, Akan Z, Kerimoglu O. Sodium alginate microneedle arrays mediate the transdermal delivery of bovine serum albumin. PLoS ONE. 2013;8:e63819.

44. Justin R, Román S, Chen D, Tao K, Geng X, Grant RT, MacNeil S, Sunb $\mathrm{K}$, Chen $\mathrm{B}$. Biodegradable and conductive chitosan-graphene quantum dot nanocomposite microneedles for delivery of both small and large molecular weight therapeutics. RSC Adv. 2015;5:51934-51946.

45. Cao X, Mohamed A, Gordon SH, Willett JL, Sessa DJ. DSC study of biodegradable poly(lactic acid) and poly(hydroxy ester ether) blends. Thermochim Acta. 2003;406:115-127.

46. Badhe RV, Bijukumar D, Chejara DR, Mabrouk M, Choonara YE, Pradeep Kumar, du Toit LC, Kondiah PPD and Pillay V. A Composite chitosangelatin bi-layered, biomimetic macroporous scaffold for blood vessel tissue engineering. Carbohydr Polym. 2017;3:1215-1225.

47. Giita Silverajah VS, Ibrahim NA, Yunus WM, Hassan HA, Woei CB. A comparative study on the mechanical, thermal and morphological characterization of poly(lactic acid)/epoxidized Palm Oil blend. Int J Mol Sci. 2012;13:5878-5898.

48. Gupta J, Gill HS, Andrews SN, Prausnitz MR. Kinetics of skin resealing after insertion of microneedles in human subjects. J Control Release. 2011;154:148-155. 